\title{
義歯食道異物の治療経験一手術症例を中心として
}

$\begin{array}{lll}\text { 佐 藤 博 信, 村山 } & \text { 公, 須田 } \text { 清 美 } \\ \text { 鈴木 武樹, 宋 圭男, 大梘 穣 治 } \\ \text { 小坂 和子, 田中 }\end{array}$

\section{Management of Denture Foreign Bodies in the Esophagus}

\author{
Hironobu Sato, M.D., Isao Murayama, M.D., Kiyomi Suda, M.D., \\ Takeki Suzuki, M.D., Keio Sou, M.D., Jyoji Ohtsuki, M.D., \\ Kazuko Kosaka, M.D., and Takashi Tanaka, M.D.
}

The Third Department of Surgery, Nihon University, School of Medicine, Tokyo

\begin{abstract}
During the last 16 years, seven cases of denture foreign bodies in the esophagus were treated at the Third Department of Surgery, Nihon University, School of Medicine. Before coming to our hospital, all cases had been treated by endoscopy in other hospital or in other department unsuccessfully. In our seven cases, two dentures were removed by esophagotomy through the external neck inscision, three dentures required thoracotomy, and remaining two dentures were removed by gastrotomy.

In general, esophageal foreign bodies can be removed by endoscopy, but in some cases whose foreign bodies could not be removed by endoscopy or in which the perforation of esophageal wall is suspected, surgical removal should be necessary.
\end{abstract}

Key words : 食道異物, 義歯異物, 異物摘出術, 食道切開術

\section{I 、はじめに}

食道異物のうち，義歯によるものは，患者が 高齢の場合が多いこと, 形状が複雑で鉤を有し ていることなどから，経口的な摘出が困難とな ることがある。食道異物は, 経口的に摘出する のが侵襲もなく理想的であり，当教室でも原則 的には治療の第一選択として内視鏡下の摘出を 試みている。しかし耳鼻科や内科，あるいは他 施設を経由している症例では，すでにファイバ ースコープや硬性鏡による摘出術が試みられて

日本大学医学部第三外科学教室

別刷請求： $\mathbf{T} 101$ 東京都千代田区神田駿河台1-8-13 日本大学医学部第三外科学教室 佐藤博信

投稿受付：1991年3月18日
おり, 経口的に摘出不可能と判断された症例が 当科に紹介され，このような症例においては手 術を考慮せざるをえない。1975年から1990年に 日本大学第三外科では 7 例の義歯食道異物の摘 出手術を経験しているので, これらを中心に若 干の文献的考察を加え報告する。

\section{II . 義歯食道異物統計}

1975年から1990年の16年間に日本大学第三外 科で入院治療した食道異物は11例で，このうち 7 例が義歯であった。異物介在部位は第 2 狭窄 部が 3 例，第 3 狭窄部が 3 例，第 1 狭窄部が 1 例であった（図 1 )。義歯異物 7 例はすべて手術 による摘出を行い, その男女比は $6: 1$ で圧倒 的に男性が多く, 年齢は 60 歳代が 4 例と最も多 かった。食道異物となった誘因は食事中が最も 


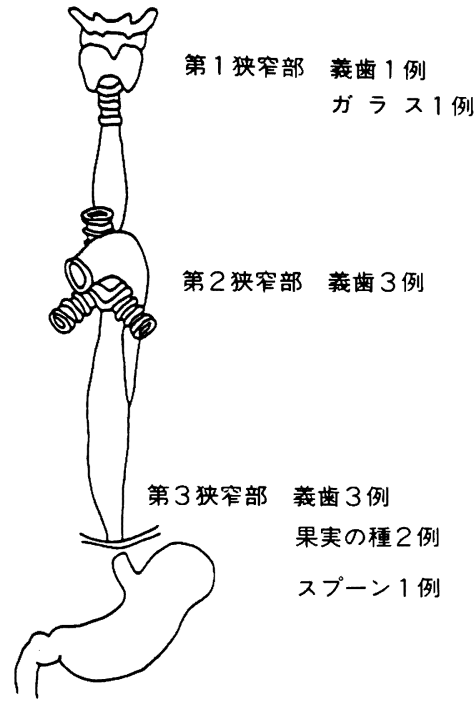

図 1 異物の介在部位

多く 6 例で，くしゃみが 1 例であった。食事の 内容も餅, 団子, 羊普などの比較的粘稠度の高 い食物が多かった。誤嚥してから当科受診まで の時間は， $7 \sim 8$ 時間のもの 2 例，28時間のも の 1 例，40〜66時間のもの 3 例，14日のもの 1 例であり, 通常は当科受診まで $2 \sim 3$ 日かかっ ている(表 1)。

\section{III. 手術適応および摘出術式}

手術した 7 例全例が他院あるいは他科にて内 視鏡による摘出術が試みられており，すべて内 視鏡的摘出不能という判断のもとに当科を受診 している。 7 例中 3 例はすでに義歯異物周囲の 食道粘膜は浮腫状に腫脹し, 鉤尖部が食道壁内 に埋没固定され, 食道穿孔の疑いが大きいと判 断された症例であった。術前の合併症は, 完全 房室ブロック 1 例, 食道アカラシア術後 1 例, 食道裂孔へルニア 1 例であった。

手術術式は頸部食道切開術 2 例, 右開胸食道 切開術 2 例, 胃切開術 2 例, 左開胸食道切開術 1 例であった(表 2$)$ 。胃切開術をした 2 例はい ずれも異物の口側への移動が不可能な症例で術 中に肛門側へ落下させ, 胃切開を施行し摘出し たものであった。

術後の合併症は食道切開部の縫合不全を 2 例 に認め,このうち 1 例は入院死亡した。死亡例
表 1 義歯異物における手術前経過

\begin{tabular}{|c|c|c|c|c|}
\hline 症例 & 年 & 性 & 誘因 & 当科受診までの時間 \\
\hline 1. & 63 & o & 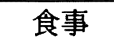 & 7時間 \\
\hline 2 & 69 & $\hat{o}$ & 食事 & 8時間 \\
\hline 3 & 73 & $\hat{\delta}$ & 食事 & 28時間 \\
\hline 4 & 66 & $\hat{o}$ & くしゃみ & 40 時間 \\
\hline 5 & 44 & $\hat{\delta}$ & 食事 & 46時間 \\
\hline 6. & 22 & $\hat{\delta}$ & 食事 & 66時間 \\
\hline 7. & 68 & $\hat{\delta}$ & 食事 & 14日 \\
\hline
\end{tabular}

表 2 義歯異物手術症例

\begin{tabular}{ll}
\hline 内視鏡にて胃内へ落下後胃切開摘出術 & 2 例 \\
右開胸食道切開摘出術 & 2 例 \\
左開胸開腹食道切開摘出術 & 1 例 \\
頸部食道切開摘出術 & 2 例 \\
\hline
\end{tabular}

は, 誤嚥から当科受診まで14日かかり，さらに 術前より房室ブロックを合併しているためぺー スメーカーを㨂入し手術を施行した症例であ る。本症例は開胸時すでに縦隔炎を併発してお り, 食道周囲は炎症が著明で浮腫状であり, 食 道切開により異物を摘出したが, 術後に食道切 開部の縫合不全から膿胸を合併し，さらには敗 血症に至り死亡した。食道異物発症から当科受 診まで14日かかり, 手術時にはすでに局所の炎 症が高度であったため縫合不全を合併したと考 えられた。その他の症例は異物摘出後にすべて 軽快退院した。

\section{IV. 摘出異物の形状と人工歯数}

摘出した義歯異物の最大径のものは, $4 \times 3 \times$ $1.5 \mathrm{~cm}$ のもので, 4 歯の補経人工義歯であっ た。人工歯数は 1 歯の症例が 3 例ともっとも多 かった。 7 例のうち 1 例を除きすべてクラスプ を有する局部床義歯であった。

\section{V. 症例呈示}

症例は44歳男性で, 食事中に義歯を誤嬹, 他 科を受診し再三にわたり内視鏡的摘出を試みた が, 胸部食道内に固定して翌日当科転科になっ た。転科時のガストログラフィンによる食道透 視では胸部上部食道に固定された義歯異物を認 めた(図 2 )。造影剤の食道外への漏出や鉤尖が 食道壁を貫いている所見は認めなかった。しか 


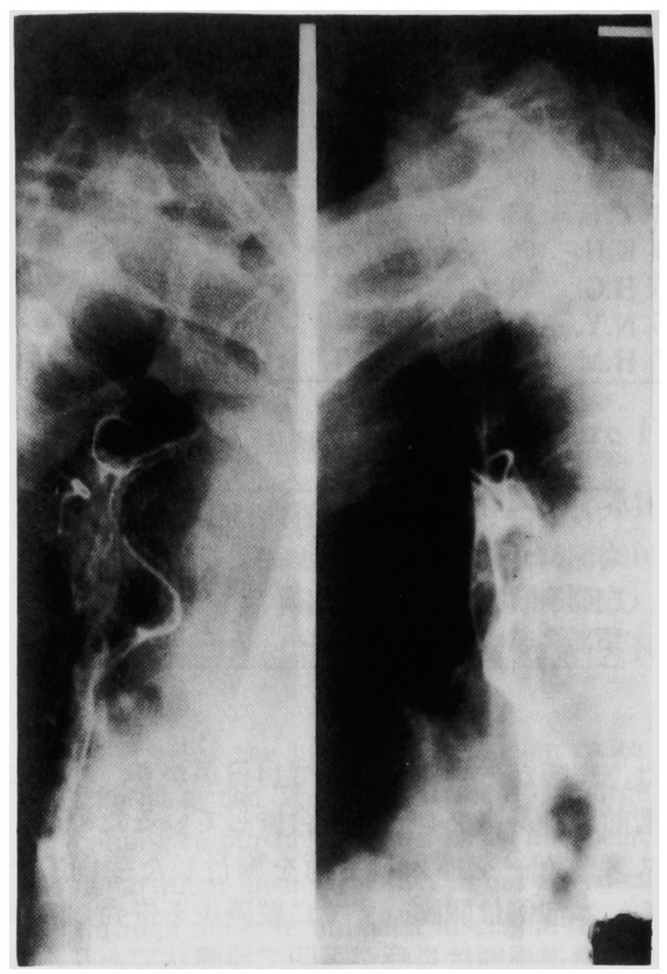

図 2 食道透視

胸部上部食道に固定された義歯異物を認妨たが，造 影剤の食道外への漏出は認めない。

し内視鏡による摘出は不可能であり，銁尖を有 するため放置すれば食道穿孔を併発する可能性 もあり手術を決定した。義歯異物は胸腔内で大 動脈弓よりやや上方に位置したため, 頙部食道 からのアプローチとした。左頸部に皮膚切開を 加え頸部食道を露出し, 食道周囲を剥離した後, 胸部食道を牽引挙上しながら同部位を切開し固 定されている義歯を鉤尖部に注意しながら丁寧 に解除し摘出した。食道切開部は 2 層に縫合閉 鎖しドレーンを留置し手術を終了した。術後の 経過は良好で術後21病日に軽快退院した。

\section{VI. 考 察}

第38回日本気管食道科学会総会のアンケート 調査では, 食道異物は気道異物の約 3 倍であり, 食道異物のうち頻度の高いものは硬貨, 魚骨, 義歯の順であった。しかし摘出術中, 術後の合 併症や重症合併症の発生原因となった異物は義 歯が最も多いと報告されている1。義歯は食道
異物としての硬貨や魚骨と比較してもその形状 は複雑で，鉤尖を有しており，いったん誤睘さ れると食道粘膜を容易に損傷する可能性があ る。

当教室に抢ける過去 16 年間に入院治療した食 道異物は11例であり，このうち 7 例 $(63.4 \%)$ が義歯であった。食道異物の症例が少ないにも かかわらず他施設と比較して格段に義歯異物の 頻度が高( ${ }^{2,3)}$ 。このことは食道異物症例の多く が当科を受診する以前に他科や他院を受診し, 内視鏡的に異物摘出術を受けている可能性があ る。そして異物摘出術を試みた結果, 摘出不能 となった症例が最終段階として観血的治療を選 択するため当科に紹介されたと考えられる。し たがって当科における症例は内視鏡的な異物摘 出に難渋した症例であり，その多くが義歯であ るということは, 義歯異物の内視鏡的摘出の困 難さを示唆していることにほかならない。

事実誤嬩から当科受診までの時間は 7 例中 5 例が24時間以上経過しており, 最長では14日の 症例もあった。食道異物は治療として第一に硬 性鏡を含む内視鏡による摘出術を試みるのは当 然であるが，摘出不能の場合には内視鏡的摘出 術に固執することなく観血的治療も考慮すべき と考える。

長期にわたる異物の介在は, 食道壁を損傷し, さらには周囲の臓器にも炎症が波及し重篤な合 併症をきたす可能性もある ${ }^{4 \sim 7)}$ 。立木ら ${ }^{2)}$ は義歯 食道異物13例のうち11例は直達鏡下の摘出で, 2 例は自然排出された経験より義歯摘出前のス ケッチ, 立体 $\mathrm{X}$ 線撮影, 造影 $\mathrm{X}$ 線撮影の重要性 を指摘しており，食道穿孔を起こしているとき 以外は安易に外切開を行うべきでないと述べて いるが，手術適応について吉田淿はそれに加え て巨大なもの,内視鏡下の摘出に失敗したもの, 危険を伴うもの，胃内に移動できたが摘出でき ないものを挙げている。また山田ら怆吐血を 伴うものも加えている。われわれの教室でも治 療の原則は内視鏡的摘出術と考えているが，他 施設や他科で十分時間をかけて内視鏡的摘出術 を試みたにもかかわらず摘出に失敗した症例に ついては，内視鏡的な方法に固執せず観血的治 療を選択している。

林ら ${ }^{10)}$ は食道異物 172 例中 2 例に食道外切開 
術を必要としたが,この 2 例はともに義歯であ ったと述べている。また食道外切開術を必要と した食道義歯異物症例は, 前坂ら ${ }^{3)}$ は50例のう ち 7 例を, 小村ら ${ }^{11}$ は 1 例, 㗈口ら ${ }^{12)}$ も 1 例を報 告している。さらに開胸術をした報告例は大畑 $ら^{13)}$ が 2 例, 河野ら ${ }^{14)}$ が 1 例, 塚田ら ${ }^{15}$ が 1 例を 報告している。

さて問題は観血的異物摘出術のうちの術式の 選択であるが, 理想は異物介在部位に近い到達 経路で, しかも手術侵襲の少ない方法が最良で あることは異論がないと思われる。その点, 頸 部からのアプローチは, 開胸や開腹するよりも 手術侵襲の面からは好ましいと考えるが，必ず しも異物が上部食道に介在しているとは限ら ず，中部から下部食道に介在する場合もあり， このようなときには頸部食道を外切開するのは 不利なアプローチといえる。

実際，われわれの症例でも義歯介在部位は食 道の生理的狭窄部のうち第 2 狭窄部, 第 3 狭窄 部が第 1 狭窄部より多かった。胸腔内食道でも 吉田6) は大動脈弓までの高さであれば頸部から のアプローチをとることが多いと述べている。 大動脈弓上縁までの高さであれば開胸せずに頸” 部食道から異物を検索することも可能である が, 介在部位がこれより肛門側の場合は困難に なる。さらに, 介在部位が胸腔内でも異物の肛 門側への可動が可能であれば, 胃内まで落下さ せ開腹し, 胃切開で摘出する方法が開胸し食道 切開で摘出するよりは容易であり, 手術侵裝も 少なく安全である。われわれも 7 例中 2 例はこ のような方法で開腹術で摘出することができ た。開胸術を行い摘出した症例は 3 例あり, こ のうち 2 例は第 2 狭窄部直下で右開胸アプロー チで, 残りの 1 例は第 3 狭窄部直上のため左開 胸アプローチで摘出した。開胸し食道切開で異 物を摘出する方法は最も手術侵襲が大きく, 危 険を伴うためできるならば避けたいアプローチ であるが, 食道穿孔が強く疑われるときは, 直 視下に炎症程度を確認し, 食道異物を摘出, さ らに損傷を修復でき, 確実なドレナージを設置 することも可能なので, 介在部位が中部から下 部食道である場合は開胸による食道異物摘出術 も考慮する必要がある。しかし全身状態が極度 に悪い状態での開胸術は慎重にすべきで, 十分
に術前, 術後の合併症に注意し管理する必要が ある。

\section{VII. ま と め}

1）過去 16 年間に義歯食道異物 7 例の摘出手 術を経験した。

2 ）異物摘出方法は頸部食道外切開術 2 例, 開胸胸部食道外切開術 3 例, 開腹胃切開術 2 例 であった。

3 ) 術後 2 例に縫合不全を認め, このうち異 物滞在期間が 14 日の 1 例は入院死亡した。

4 ）開胸術による異物摘出術は手術侵襲も大 きく, 十分に術前, 術後の合併症に注意し管理 することが必要である。

\section{文献}

1) 松永 喬, 進 武幹, 渡辺 宏・他: 最近の気 道・食道異物の合併症などに関する国内アンケ 一下集計. 第38回日本気管食道科学会総会学術 講演会パネルディスカッション「気道・食道異 物の偶発症とその対策」テキストpp. 61-76, 1986.

2 ）立木 孝, 村井和夫, 佐藤護人・他: 義歯食道 異物の診断と治療に関する 2,3 の知見. 日気 食会報, 29：221-229，1978.

3 ) 前坂明男, 宮崎為夫, 徳田紀九夫・他：わが教 室 43年間の義歯食道異物症例の統計的観察. 日 気食会報，29：323-327，1978。

4 ) 西村忠郎, 杉山和子, 小町清彦・他：食道穿孔 と気胸を合併した食道義歯異物の 1 治験例。日 気食会報, $28: 139,1977$.

5 ) 藤田博正, 野田辰男, 畠山忠信 - 他：義歯誤飲 による大動脈食道穿孔の 1 例報告およびその文 献的考察。日胸外会誌, 25：1490-1496, 1977.

6 ) 渡辺 誠, 芳賀通郎, 関 惇・他：特異な経 過をたどった異物（義歯）による食道穿孔症例。 日気食会報, $29: 133,1978$.

7 ) 中山尚樹, 吉田昭男, 新垣 馨・他：気管食道 瘦を生じた食道異物症例. 日気食会報, $40 ： 488-$ 493, 1989.

8 ) 鍋谷欣市, 掛川暉夫 編集（吉田 操）：食道手 術のすべて, 食道異物, pp. 182-187, 金原出版, 東京, 1987.

9 ) 山田守正, 阿部麻子, 奥井寛三・他：歯科に関 連のある食道異物, 気管・気管支異物について。 日歯麻誌，17:329-337, 1989.

10）林 光夫, 福田 論, 滝沢昌彦・他：当教室に 扔ける過去10年間の食道異物の統計的観察. 耳 鼻, 34：673-676, 1988.

11）小村 良, 佐藤英治, 酒井利忠・他：食道抢上 び気管気管支異物の統計的観察。耳鼻臨床, 補 $27: 170-182,1988$. 
日気食会報，42（6）, 1991

12）桶口彰宏, 鈴木 徹, 斉藤 彰・他：開院以来 10 年間の気道食道異物の統計的観察. 日気食会 報, $34: 255-259,1983$.

13）大畑正昭, 飯田守, 遠藤英利・他：開胸手術 によって摘除した食道異物（有鉤義歯）の 2 治 験例。日気食会報，28：138, 1977 .
14）河野もと子, 清田隆二, 松山博文 - 他：食道穿 孔 2 症例. 日気食会報, $39: 221,1988$.

15）塚田邦夫, 久米敏文, 片岡卓三・他：食道気管 支掼を併発した食道異物 (義菌)の 1 例。日救急 医会関東誌，3：184-185, 1982. 